\section{ECONOMICS}

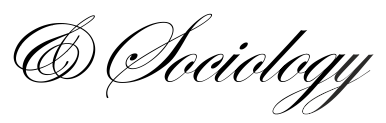

\author{
Emília Krajňáková, \\ Alexander Dubcek University, \\ Trenčn, Slovakia, \\ E-mail: \\ emilia.krajnakova@tnuni.sk \\ Sergej Vojtovič, \\ Alexander Dubcek University, \\ Trenčin, Slovakia, \\ E-mail:sergej.vojtovic@tnuni.sk
}

Received: July, 2016

1st Revision: October, 2016

Accepted: December, 2016

DOI: $10.14254 / 2071-$

789X.2017/10-1/23
Krajňáková, E., Vojtovič, S. (2017), Struggles of Older Workers at the Labour Market, Economics and Sociology, Vol. 10, No. 1, pp. 319-333. DOI: 10.14254/2071789X.2017/10-1/23

\title{
STRUGGLES OF OLDER WORKERS AT THE LABOUR MARKET
}

\begin{abstract}
This study focuses on the issue of ageing population and the position of older employees at the labour market. We look into theoretical approaches towards the so called "positive ageing of population" and employability of older generations. In addition, we have conducted an empirical research, which allowed us map the employability of workers aged 50 and older in Slovakia. Consequently, we tried to determine the reasons why employers lack interest in employing older employees and how older employees themselves evaluate their position at the labour market today. Our findings suggest there is a discrimination against older workers, as well as inadequacy of state employment policy in the face of demographic changes and missing out on the work potential offered by older generations. The government could contribute to the solution of this problem through affirmative action, for example, by reducing the levy burden, which would deter employers from laying off older workers, who could thus continue sharing their knowledge stemming from profound work experience.
\end{abstract}

JEL Classification: J 40, SJ14 Keywords: positive ageing, risk groups on the labour market, older applicants for jobs, discrimination.

\section{Introduction}

Balanced demographic development is one of the basic preconditions for successful development of any society. Current changes in demographic composition of population, especially in developed countries, pushed the issues of population development to the forefront of public attention and found their way into the interest of scientists, businesses, and politicians. Deceleration of population growth and subsequent population ageing bring in new challenges for economy, social policy and politics as a whole, and in general, it significantly influences overall development of both the country and the society (Svagzdiene, Kuklyte, 2016). Deepening population imbalance impacts economic growth, flow of investments, range and structure of consumption, labour market, pension system, and social, cultural and moral transfers between generations (Fuinhas et al., 2016).

The phenomenon of population ageing is a result of long-term trends in reproductive behaviour in almost all the countries, and not necessarily only in developed ones (Nygård et al., 2011; Wallin, Hussi, 2011;Kordos, Karbach, 2014).Therefore, there is an evident interest to the works on demographic development, and more attention today is paid to the current trends and possibilities of its regulation (Kate, 2013; Lisiankova and Wright, 2009). For example, much of the existing research on population aging has focused on its impacton 
developed countries, particularly those in Europe and North America. One study looked into how unequally population aging distributes risks in securing socio-economic resources for the wellbeing of individuals in later life between developed and developing countries (Higo, TA Khan, 2014). In another study, Gillion (1991) emphasizes that over the next 50 years almost all OECD countries will experience a dramatic ageing of their population structures. This process will become the burden, especially in terms of taxes or social security contributions, placed on active members of population (Skare, Siinkovic, 2016). This paper, which compares the potential developments in France, Germany, Japan, the Netherlands, Sweden and the USA, concludes with two, fairly obvious, caveats: first: countries most generous to their older generations are also the most vulnerable when it comes to facing the ageing problem; second: all those developments which might offset the consequences of ageing populations would also be capable to improve incomes and welfare even if the ageing problem did not exist (Gillion, 1991). Multiple studies have looked into trends in demographic developments and the issue of ageing population in the EU countries (BecerraAlonso et al., 2016; Carbonaro et al., 2016), Scotland (Lisenkova, Mérette, 2014), Germany (Kluge, 2012), Serbia (Radivojević et al., 2016), Australia (Hughes, 2016), etc.

Demographic development in Slovakia is perceived in the context of global population development. Despite the fact that multiple demographic processes develop in Slovakia with some time delay, population problems faced by Slovakia are very much similar to those in Western developed countries (Bleha, Vaňo, 2015). The singularities of demographic processes in Slovakia are influenced by lower levels of economic and social development, since demographic development in less developed countries differs from developed ones. However, the process of integration and gradual narrowing of the gap between the countries resulted in multiple economic and social processes, including demographic ones, starting to follow the same pattern as in developed countries (Androniceanu, 2015).

Current demographic development is included in the research activities and reflections of expert community, and there are attempts to find the solutions for the problems it presents on various levels of societal hierarchy (Ilmarinen, 2009). Simultaneously, based on the current demographic situation, there is a multitude of analyses, projects, measures in social legislation, and changes in the pension and social security systems which are being implemented as a response to this issue. However, the question remains, whether these attempts truly aim at and impact the real situation of specific people, who through no fault of theirs find themselves in a position of disadvantaged applicants for jobs and thus fall into the so-called risk group at the labour market. Individuals mentally burdened by this situation,in which they have to face economic, social, and moral discrimination, often battle existential problems.

Within the scope of this article we focus only on some of these questions; more specifically, on the reasons why the category of employees aged over 50 are considered to be a risk group in the administrative and legal system of Slovak Republic, and therefore, the members of this category become disadvantaged when applying for a job. In the first part of the article we analyse theoretical approaches to researching the processes of demographic ageing of population as well as the position and subsequent problems that the older generation of employees face at the labour market. The second part of the article introduces methodological basis for our own research, and methods and techniques through which we obtained the data. And lastly, the third part of the article contains our own findings and their explanation. 


\section{Theoretical questions regarding ageing labour force and its position on a labour market}

Ageing of the population is a global demographic process, which is most prevalent in the developed countries (Kate, 2013; Lisiankova, Wright, 2009). This state of demographic development of the population is a result of previous economic and social development of the society. Technological and scientific advances and growth of the labour effectivity created the conditions that lead to decrease in mortality rate, increase of the average life expectancy, and better healthcare for the population. $21^{\text {st }}$ century saw the most radical increase in human life expectancy (Rychtařiková, 2002). For instance, the average life expectancy at the time of birth increased on average by 10 years in the EU countries over the last five decades. Median age for European population rose from 35.2 in 1990 to the current 40.9. The number of people in the EU above the age of 60 grows by more than 2 mil. a year. The trends showing the rising ratio of older generations in the overall population structure confirm the scope and the tempo of demographic changes in Europe (Androniceanu, Ohanyan, 2016). It is expected that the share of citizens over the age of 50 will rise to $42.2 \%$ in 2020 from the $31.3 \%$ in 1990 (Kate, 2013, p. 14).

Ageing of the population causes the drop in the ratio of child population ( 0 19 years), and it is anticipated that this ratio will fall from the current $21.3 \%$ to $19.2 \%$ in 2050. The share of people in productive age ( $20-64$ years) is expected to drop to $52.2 \%$ by 2050. And the ratio of people in post productive age $(65+)$ is expected to rise from the current $17.4 \%$ to $28.6 \%$ by 2050 (Páleník, 2014, p. 5). The demographic processes mentioned above are accompanied by the decline in the natality, which only escalates the ageing of the population. Low natality can be named among the main reasons for the quick demographic ageing in the countries of Western, Central, and Eastern Europe (Potančoková, 2005).

These demographic shifts in the structure of the population cause a variety of complex economic, social and psychological problems, which have become a point of interest of the expert and scientific community. The most relevant theoretical instrument when it comes to analysing and evaluating the topic of ageing population is the concept of the so called active, successful or positive ageing (Tyrovolas et al., 2015; Kelly and Lazarus, 2015; Latorre et al., 2015; Ji et al., 2015; Moulaert and Biggs, 2013). This concept focuses on determining the conditions and factors that impact the vitality of older generations as one of the main parts of the process of active ageing (Carra et al., 2016).

Within the conceptualization of the process of ageing itself and determining the factors improving the vitality of ageing population, K. Nilsson conducted a discursive analysis of 128 articles focusing on this topic (Nilsson et al., 2016). The resulting findings suggest that the main factor influencing the vitality of older people is biological ageing; i.e. the health of people in relation to their physical and mental abilities. The second factor impacting the vitality of ageing population is the chronological ageing, which is determined by the retirement age and economic stimuli in the society, organizations, and businesses. Another factor, social ageing, is based on being a part of certain social groups, on the positions of managers, organisations and family members, on the free time activities, etc. The last factor of active ageing is mental (cognitive) ageing, which is determined as a certain rate of motivation, as a sum of meaningful activities or competences and skills in a work life. Nilsson emphasizes that nowadays the society focuses mostly on the chronological ageing and seeks ways to raise the retirement age while considering present pension systems.

The findings gained in the process of researching the processes of positive ageing suggest that there is a connection between positive ageing and the improvement of public health and creating favourable life conditions. One of the researches revealed additional interesting findings, mainly that an important instrument to achieving better health and active 
ageing is social capital, i.e. being a part of the community's activities, improving on the social trust, fostering intergenerational support, and removal of conditions leading to seclusion of older people (Koutsogeorgou et al., 2014). The older people's awareness of the process of ageing and the fact that they themselves identify with the status of an ageing person also contribute to the positive perception of the ageing process in the workplace (Cheung and $\mathrm{Wu}$, 2014).

Another study, which came up with particularly interesting conclusions, aimed to determine the perception of successful ageing in the context of intergenerational perspective. (Kelly and Lazarus, 2015). Representatives of three different generations were approached, specifically university students, parents and grandparents. Using qualitative methods of data collection and analysis the authors formed five conceptual categories that relate to the perception of successful ageing. These include wisdom, health, financial stability, remaining active, and contentment (Kelly and Lazarus, 2015, pp. 238-239). According to the authors, each of these conceptual categories plays in important role in the perception of successful ageing across the representatives of all generations, who selected contentment to be the most valuable aspect of successful ageing. At the same time, these categories represent the main topical model of the overall bio- mental- social concept of successful ageing.

A group of Australian sociologists came up with findings that emphasize the importance of this approach to researching the concept of positive ageing and neoliberal policy of its realization (Aberdeen and Bye, 2013). Additionally, they aim to demonstrate the advantages that could be gained from the critical analysis of positive ageing, especially because government institutions and representatives on all levels seem to prefer such ageing policy, which tries to subordinate the social needs of elderly to the needs of economic growth and labour market (Hughes et al., 2016).

Favouring the policy which subordinates the concept of positive ageing of the population to the economic growth and labour market is a dominant approach of the absolute majority of both academic and executive branches. This approach represents the second important theoretical and empirical methodology of analysing the issue of ageing population; a methodology that accentuates the importance of the needs of labour market and employability of older workers. This approach is then subdivided into two directions.

The first one looks into the general physiological and psychosocial factors that influence older generations' overall ability to work and their current employability (Weller, 2007; Sanders and McCready, 2010). In the context of this approach, one looks into the issues of prevention and health protection while working in order to preserve older employees' ability to work (Ilmarinen, 2009b; Nygård et al., 2011; Ilmarinen, 2012). In addition, one also studies problems that are associated with the health condition of older workers in different branches of economy and in different professions and the possibilities of older workers' reentry into the employment after they have been laid off. Ageing population and diminishing labour force prompted public discussion about health, employment and social policy (Moulaert and Biggs, 2013).Research into this issue that worked with the sample of selected workers within 55-64 age group concluded that their health condition and the risk of their termination of employment narrowly correlates with specific types of employment. For example, it is mostly older workers in shops and production companies, and especially men, whose health condition is worse, and who therefore more often terminate their employment, when compared with their counterparts in other professions (McPhedran, 2012).

The second direction focuses on the specific behaviour of older workers, on their perception of the ageing process at the workplace, especially in relation to interpersonal relations with other co-workers, and on the way they identify their position (Cheung and $\mathrm{Wu}$, 2014). Starting from the premise that younger and older people meet and communicate at workplaces, it is a natural progression that one should analyse principles of solidarity between 
the generations in work environment, especially with regards to the multidisciplinary (mainly sociological) context. This allows us to understand the complexity of intergenerational relations in work environment. At the same time it provides us with methods to evaluate older workers' knowledge and experience, and how these could be passed on to the younger generations. All of this builds a base for realistic and effective solidarity principles in workplaces (Barabaschi, 2015; Srovnalikova, Karbach, 2016).

The constantly rising requirements on the applicants' qualifications and experience along with the lack of young workers with necessary skills on labour markets of developed countries force us to look for new mechanisms that would allow us to keep the older generations in the state when they are capable of working and remaining an active part of the labour market for longer time. Simultaneously, the overall combination of structural changes in the industrial production and in the professional profile of jobs, the shortage of workers with required qualifications, and the ageing labour force poses a challenge for employers, politicians, and researchers. That is the reason why the ageing labour force is an issue affecting all age groups and not necessarily only the elderly themselves (Green, 2003).

We can assume that changing trends on the labour market, the constantly growing importance of computer and other new technical skills, and the emphasis on customer care and teamwork are challenging especially for older workers, who thus have to continuously add to and improve their knowledge and skills. These are the conclusions introduced by the study authored by German researchers, which explored the connection between innovative production, fields with the high concentration of skills and competences, and the favourable demographic and age structure of population (Gregory and Patuelli, 2015).

The concept of positive ageing of population is almost entirely missing in the public and expert discussions. The most attention is given to the problem of employing the older generations in the context of the generally high unemployment rate. People over the age of 50 are one of the biggest social groups that face obstacles when looking for a job. Despite the fact that the overall average economic activity rate of people in the $50-60$ age group almost doubled over the last decade (this was caused predominantly by postponing the retirement age), the unemployment rate within this group of workers continues to be a pressing economic and social problem for the society (Bednárik et al., 2014, pp. 19-20).However, with the unemployment rate being high in Slovakia in general, the attention of representatives of both the academia and politics is focused mainly on the unemployment of high school and university graduates and those who had been unemployed in the long term. Unemployed older people of pre-retirement and retirement age are not perceived as a potential source of either labour force or economic growth. That is why the issue of older people's economic activity and their position on the labour market currently finds itself outside of the scope of interest of both politicians and employers.

In addition, the category of people above the age of 50 is in Slovakia considered to be a high risk and a disadvantaged group on the labour market (Burcin, Kučera, 2002). The Working Papers prepared by the European Commission emphasize that, despite the significant progress made during the last decade, older workers still remain to be one of the potentially untapped sources of labour force. In 2013, the employment rate of people within the 55-64 age group was $44 \%$ in Slovakia, while the EU average was 50.2\% (Pracovný dokument, 2015, p. 19).Slovak republic, as an EU member state, partakes in the strategy Europe 2020, and its National Reform Plan sets the target for the employment rate to $72 \%$. For comparison, in Sweden the employment rate was 80\% in 2014 (Eurostat, 2016). In this context, the concept of positive ageing within the labour market is perceived in a very narrow way and only through the prism of overall high unemployment rate. 


\section{Research objective, methodology and data}

Citizens aged 50 and over form one of the most numerous socio-demographic groups in the Slovak population that is having trouble with finding a position on labour market and problems with employment. Within professional and public discourse, this group is marked as a risk group. As we have already emphasized, the main task of this study is to answer the question why this population group with decades of job experience, has problems with employment once it reaches a certain age and is therefore seen as a risk group in terms of its employability.

To achieve this goal, in addition to the assessment analysis and exploring the issue of ageing workforce and its enforcement not only on the Slovak labour market but abroad as well, we used empirical data that we acquired through executing an empirical research. This was executed in 2015, and titled "Trends in corporate recruitment policy and personnel work". The survey was conducted by means of a structured interview. Managers and employees of selected companies were chosen to be an object of our investigation. The sample consisted of randomly selected 34 small and medium sized enterprises from three regions of Western Slovakia. We conducted a structured interview with 339 employees of these enterprises. A particular group of respondents were top managers of enterprises, specifically 58 of them, who were selected on the basis of their management positions in company. Head directors of selected companies, deputy directors and, if applicable, personnel departments directors were classified in here. The rest of 281 respondents were representing the employees of these enterprises, which were selected according to the statistical indicators of socio-demographic structure of those employed in manufacturing in Slovakia. The sample was randomly selected and is representative for the manufacturing companies in the three regions we focused on.

For the purposes of our research, we have used the responses for the following closed question of structured interview: "Why do you think workers aged 50 and over have difficulties with their employability on the labour market and at work?" The offered answers have been constructed in the process of pilot survey where open question was offered to 48 respondents, and where it was requested to appoint five factors why employees aged 50 and over have difficulties on the labour market and at work. As a result, we obtained 32 different answers that represented a semantic field of issues as seen by different employees' categories in manufacturing companies and not researchers. We have selected 12 most frequently repeated answers from the responses in the pilot survey to be among the offered answer to the question in main survey (See Table 1). At the same time, in the main survey the respondents were asked to choose five options, which they see to be the most important when it comes to why workers aged 50 and over have difficulties on the labour market and at work. Therefore, instead of having obtained 399 responses, as it would be according to the number of respondents, we could work with five times more, i.e. 1695 responses.

After conducting the empirical research and processing the obtained statistical data for the purposes of analysis and assessment within this study, answers to questions for three target groups of respondents were generated. The first one is the previously mentioned group of top management representatives from selected enterprises. Another group was represented by 155 employees from selected companies under the age of 50, including 27 administrative and professional staff, and line managers. The third group consists of 127 employees of different socio-demographic groups aged 50 and over, including 16 line management representatives, professional, and administrative staff. The multiple choice questions and target groups of employees constructed in this way allowed us to conjure up an idea on 
employers' views represented by enterprises' top management, the majority of enterprises employees under the age of 50, and risk group representatives aged 50 and over.

Statistically significant differences between answers of defined groups regarding the problems on the labour market that are faced by the older workers were calculated using Spearman's correlation coefficient with a significance level of 5\%. Statistically significant differences in percentages indicators of respondents' answers were calculated by means of the statistics.

\section{Results and discussion}

Top managers of enterprises are one of the most important groups of selected respondents, whose opinions contribute the most when answering the question why workers aged over 50 are considered as a risk group in the labour market. This group is composed through our exploratory selection of the directors of SMEs, their representatives and directors of personnel departments. These people are the employers who recruit, evaluate worker's skills and qualifications, employ, assess the quality of their work, work performance, motivate, lay off, and perform other personnel related actions. It means that these staff members should be the most experienced experts in assessing the quality of the labour force. In this respect, their opinion on the work and skills of older workers for the purposes of this study are very important. Therefore, we consider this group of respondents in our survey to be the expert statistical unit.

According to the employers, the biggest problem is that the older workers are not willing to work with higher performance. (See Table 1). Employers further emphasized the difficulties in adapting to the new work conditions, lack of necessary qualifications, and unwillingness to partake in a further training. The value of chi-squared statistics $\left(\chi^{2}=186.5\right)$ indicates that the number of replies and its percentage are statistically significant at the number $(\mathrm{N})=38.13 \%$ and higher values $\left(\chi^{2}=186.5\right.$ with the significance level of $5 \%$ or $\alpha$ $=0.05$ ). Other factors, according to the employers, have no significant impact on older workers in the labour market and at work. This means that, at least according to employers, the problems of older workers are mainly due to their personal characteristics and not the often discussed so-called generational characteristics of older people, as a lack of language and computer skills; these are not an obstacle in the labour market according to the response of employers.

Researchers from other countries came up with findings similar to ours. For example, P. Bohle et al. (2010) points out that the work performance of older employees depends on their health, and that the work ability, i.e. the capacity to meet the physical, mental, and social demands of a job, has been linked to positive health outcomes for older workers. However, work characteristics seem to be more critical than workers' individual capacities. Contingent work is generally associated with poorer outcomes, and since older workers are more likely to be contingent, there are special implications for their safety and health. Riach (2007)describes how the social construction of the 'older worker' may marginalize and contribute towards age inequalities through three discursive strategies: contextualizing the problem, essentializing older worker characteristics and ventriloquizing older workers. Adler and Hilber (2009) estimate a low rate of new hiring for older workers aged 55 to 64, with low turnover and net outflows, but also with substantial variability among industries. On the other hand, our findings regarding the further education of older workers differed from those presented in the British study that concluded that men over 50 remained among those least likely to have been offered training by employers. (Canduela et al., 2012) The study also pointed out significant inequalities in participation, suggesting a polarization in access to jobs that offer opportunities for training and progression (Canduela et al., 2012). 
Employees of enterprises aged under 50 agree with the employers that the older workers are unwilling to work with higher levels of commitment, they agree about the difficulties of older workers to adjust to the new work conditions and about the lack of qualifications. Their evaluations are similarly placed in most rankings as regards to the number of responses - the first three places. This group of respondents greatly expanded the set of relevant factors that, in their view, cause problems for older workers on the labour market and at work. Employees aged under 50 think that older workers are not prospective for the company, they do not speak foreign languages and their computer skills are insufficient. The values of these factors are statistically significant at $\mathrm{N}=64,18 \%$ and higher values $\left(\chi^{2}=\right.$ 331.8 with significance level at $5 \%$ or $\alpha=0.05$ ).

The evaluation of this group of employees shows an obvious shift from the personal qualities of older workers to external, impersonal factors. These are mainly such factors as the lack of interest of companies to educate older people, their failure to see perspective for and the potential of older workers, and they talked about discrimination in the workplace. While employers do not identify with the named factors, the employees aged under 50 evaluated the factor - "They are not prospective for the company" as much more important and it moved up to fourth place, and also at the level of statistical significance (see Table 2). Two other factors, despite the fact that they remain below the level of statistical significance, moved from the last ranks up to the seventh and eighth position.

Table 1. Factors that cause problems with the placement of older workers (50 years of age and over) on the labour market and at work (number of workers*/number of responses and \%)

\begin{tabular}{|c|c|c|c|c|c|c|}
\hline \multirow{2}{*}{ Factors } & \multicolumn{2}{|c|}{ Top Management } & \multicolumn{2}{|c|}{$\begin{array}{l}\text { Employees under } \\
50 \text { years of age }\end{array}$} & \multicolumn{2}{|c|}{$\begin{array}{c}\text { Employees of } 50 \\
\text { years of age and over }\end{array}$} \\
\hline & $\begin{array}{l}\text { Number of } \\
\text { responses }\end{array}$ & $\%$ & $\begin{array}{l}\text { Number of } \\
\text { responses }\end{array}$ & $\%$ & $\begin{array}{l}\text { Number of } \\
\text { responses }\end{array}$ & $\%$ \\
\hline $\begin{array}{l}\text { Unwillingness to work with } \\
\text { higher level of commitment }\end{array}$ & 55 & 19 & 132 & 17 & 24 & 4 \\
\hline $\begin{array}{l}\text { Difficulties with adapting to } \\
\text { new work conditions }\end{array}$ & 52 & 18 & 101 & 12 & 15 & 2 \\
\hline Insufficient qualifications & 49 & 17 & 136 & 18 & 32 & 5 \\
\hline $\begin{array}{l}\text { Unwillingness to take part in } \\
\text { further education and training }\end{array}$ & 38 & 13 & 31 & 4 & 17 & 3 \\
\hline Lack of language skills & 23 & 8 & 72 & 9 & 91 & 14 \\
\hline Low computer literacy & 19 & 6 & 68 & 8 & 83 & 13 \\
\hline Lacking sufficient education & 15 & 5 & 26 & 3 & 42 & 7 \\
\hline $\begin{array}{l}\text { Having inadequate } \\
\text { requirements regarding work } \\
\text { conditions }\end{array}$ & 14 & 5 & 12 & 1 & 8 & 1 \\
\hline Having health problems & 9 & 3 & 9 & 1 & 45 & 7 \\
\hline $\begin{array}{l}\text { Firms not having an interest to } \\
\text { further train/educate the } \\
\text { workers }\end{array}$ & 8 & 3 & 52 & 7 & 80 & 13 \\
\hline $\begin{array}{l}\text { The workers are not } \\
\text { prospective for the company }\end{array}$ & 5 & 2 & 94 & 11 & 103 & 16 \\
\hline $\begin{array}{l}\text { Workers are discriminated at } \\
\text { work }\end{array}$ & 3 & 1 & 37 & 5 & 95 & 15 \\
\hline Total & $58 * / 290$ & 100 & $154 * / 770$ & 100 & $127 * / 635$ & 100 \\
\hline
\end{tabular}

Source: Author's survey. 
Opinions of the older workers themselves differ from those expressed by the two groups discussed above. While employers consider the lack of work commitment, difficulties in adapting to the new work conditions and insufficient skills and unwillingness to learn to be the biggest obstacles, the workers aged 50 and more reported these problems under the level of statistical significance. The level of statistical significance in the assessment of workers aged 50 and over is at the level of 52 responses from a total of $635(\mathrm{~N}=52$ or $8 \%)$ and higher values $\left(\chi^{2}=256.4\right.$ with a significance level $5 \%$ or at $\left.\alpha=0.05\right)$. Therefore, according to their own assessments, the statistically significant problems compromising their position on the labour market are: the fact that they are not prospective for the company, discrimination at work, lack of language skills, lack of IT skills, and the companies' lack of interest to educate them. Three of the named factors are statistically significant in the evaluation of workers under 50 years old (not prospective for the company, lack of language skills and lack of computer skills). However, according to the evaluations of employers, none of these factor in the problems that the older workers face on the labor market.

Table 2. Factors causing problems on labour market and at work for people aged 50 and over, ranked according to the number of responses (maximum - 1, minimum -12)

\begin{tabular}{lccc}
\hline Factors & $\begin{array}{c}\text { Top } \\
\text { management }\end{array}$ & $\begin{array}{c}\text { Employees } \\
\text { under 50 years } \\
\text { of age }\end{array}$ & $\begin{array}{c}\text { Employees } \\
\text { aged 50 and } \\
\text { over }\end{array}$ \\
\hline $\begin{array}{l}\text { Unwillingness to work with higher level of } \\
\text { commitment }\end{array}$ & 1 & 2 & 9 \\
\hline $\begin{array}{l}\text { Difficulties with adapting to new work } \\
\text { conditions }\end{array}$ & 2 & 3 & 11 \\
\hline Insufficient qualifications & 3 & 1 & 8 \\
\hline $\begin{array}{l}\text { Unwillingness to take part in further } \\
\text { education and training }\end{array}$ & 4 & 9 & 10 \\
\hline Lack of language skills & 5 & 5 & 3 \\
\hline Low computer literacy & 6 & 6 & 4 \\
\hline Lacking sufficient education & 7 & 10 & 7 \\
\hline $\begin{array}{l}\text { Having inadequate requirements regarding } \\
\text { work conditions }\end{array}$ & 8 & 11 & 6 \\
\hline Having health problems & 9 & 12 & 5 \\
\hline $\begin{array}{l}\text { Firms not having an interest to further } \\
\text { train/educate the workers }\end{array}$ & 10 & 7 & 1 \\
\hline $\begin{array}{l}\text { The workers are not prospective for the } \\
\text { company }\end{array}$ & 11 & 4 & 2 \\
\hline Workers are discriminated at work & 12 & 8 & \\
\hline
\end{tabular}

Source: Author's survey.

We used Spearman's Correlation Coefficient to determine the differences between the three groups of respondents. The calculated correlation coefficient values show that the opinions of the employers and the employees over 50 differ. The value of $(r)$ is 0.54 and the two-tailed value of $(p)$ is 0.07 . By normal standards, the association between the two variables would not be considered statistically significant. Correlation dependence is absent in the evaluation of employees under the age of 50 and that of the employees over 50 years old $(r=0.07$ when $p=0.83)$. The evaluation of these two groups of employees shows neither similarity nor relevant differences. Although technically a negative correlation, the relation between both variables is only weak (the nearer the value approaches 0 the weaker the 
relationship). Nevertheless, the answers are contradictory in the group of workers aged 50 and more and in the group of employers. The value of $(r)$ is -0.62 and the two-tailed value of $(p)$ is 0.03 . By normal standards, the association between the two variables would be considered statistically significant. Economic reasons alone do not explain the findings regarding the different points of view of employers and older workers. In this case, the probable reasons are primarily intergenerational and cultural differences, stereotypes, group interests, etc.

The overall average rankings of factors causing problems for older workers are as follows: lack of qualification (the largest number of responses $-13 \%$ ), insufficient work commitment, not being prospective for the company, lack of language skills, lack of computer skills, the difficulties in adapting to the new work conditions (10\%). The level of statistical significance is at the level $\mathrm{N}=141(8 \%)$ and above. It is necessary to point out that the differences between above named factors do not exceed three percentage points. Therefore, the hierarchy between named factors is statistically insignificant. Factors such as the lack of interest of companies to educate older workers and a discrimination against older workers at work are slightly below the level of statistical significance.

While many of the factors that cause problems for older workers can be assigned to the so-called external and social problems that are associated with the period change, then factors such as lack of commitment and the difficulties with adapting to new work conditions clearly relate to the personality problems, and are due to the decline of some abilities or health status of older workers. For example, a study realized on the sample of older workers points out that ageing workers often showed a decline both in the cognitive function and in adaptability (Cheung et al., 2016, pp. 168-171). The importance of deterioration in health of older workers was emphasized in the survey carried out in Australia (McPhedran, 2012). Professor Juhani Ilmarinen of the Research Center for Gerontology in University of Jyväskylä in Finland points out that health and physical ability of older people is deteriorating. He also explains the positive aspects of the ageing process, and, by measuring workplace performance, he underlines that work experiences of older people compensate for the decline of some basic cognitive abilities, such as memory and psychomotor skills (Ilmarinen, 2012).

The remaining factors (lack of qualifications, not being prospective for the company, lack of language skills and the lack of computer skills) are not related to the age of employees as such, but they rather belong to a social problem which should be addressed by employers and the state. A special attention should be given to the discrepancy shown when employers feel that older employees are unwilling to further educate themselves, whereas the older workers themselves complain about the lack of companies' interestin providing further education or training for them. If we assume that older workers truly are not prospective for the company (as it was assessed by the both groups of employees included in our survey), then the lack of companies'interest in educating older workers would be rather logical. For example, the survey that focused on the educational activities of companies found evidence thatfurther education was not offered for older workers, suggesting that the "inequalities in training"are still relevant (Taylor, 2013).

Beck (2014) conducted a survey, in which human resources professionals, managers and business owners were asked how the employers evaluate the role of education and training for older workers with regard to the increasing number of older workers on the labor market. In response to the question - what learning opportunities were provided for older workers - respondents implicitly conceded that there were only very few educational opportunities for older workers (Beck, 2014). The lack of educational opportunities for older workers is especially regrettable when considering the multitude of potential positive effects. A recent study indicates that educational programs and job training enhance employment skills and overall physical and mental condition of older people, improve life satisfaction, 
enhance emotional well-being and reduce the symptoms of depressive states (Latorre et al., 2015).

The claims regarding the discrimination of workers based on their age are supported by findings of multiple researchers. For example, D. Neuman (2009) offers evidence on age discrimination in U.S. labor markets and on the effects of the Age Discrimination in Employment Act (ADEA) in combating this discrimination, focusing on the challenge of population ageing facing the U.S. economy in coming decades. Van Dalen et al. (2009) conducted a comparative survey among employers from four European countries (Greece, Spain, the Netherlands and the United Kingdom) hints at discrimination against older workers. The results show that in spite of the perceived challenges, employers take no substantial measures to retain and recruit older workers or improve their productivity. Only employers in the United Kingdom seem to recognize older workers as a valuable source of labour supply and act accordingly (Van Dalen et al., 2009). Other authors present the findings of a study on age discrimination against older workers (Cheung et al., 2010) and furthermore that the question of age discrimination is becoming increasingly important (Wale, 2011).Other studies also point the occurrence of age discrimination in organizations. (Cheung et al., 2016; Nilsson, 2016; Moulaert and Biggs, 2013).

One can also mention a survey that studied the situation of older people in society (IVO, 2012) which concluded that the absolute majority of respondents think that older people have worse status in society (73\% respondents). When answering the multiple choice question "In what areas there is an unfair treatment or discrimination against older people most often?" the highest number of respondents (50.6\%) selected "labour market, jobs, job search, and ridicule in the workplace". Other selected areas were: "health and healthcare" (33.9\%), "banking and insurance"(27.8\%) and "security, crime"(12.4\%) (IVO, 2012, p. 6). The results of this survey support our findings that older people in Slovakia are disadvantaged or risk group on the labor market.

\section{Conclusion}

The results of our analysis and investigations suggest that the problems of success on the labor market and at work 50 years of age and older workers are mainly due to social factors. In this case, we can only assume that aging process can cause difficulties in success on the labor market and at work of older people only to a small extent. Therefore employment, social, personality and other aspects of human life in the context of aging process will require more extensive and more detailed analysis and investigations.

Based on our findings, the main factors are the lack of qualification, deadness of end for the company, lack of knowledge of foreign languages, low computer skills which "makes" 50 years of age and older employees disadvantaged and at risk groups on the labor market and at work. A worker who has been employed for decades and at age 50 became insufficiently qualified and does not have lots of other necessary qualifications for the job and skills - this regularity, it would be very difficult to justify age and aging employee. It just indicates that workers at work had not the opportunity to upgrade their skills and acquire other skills that require technological and economic progress. The cause of this condition, as a rule, is discrimination against older workers in access to education, vocational counseling, employment services, etc.

We can agree to a certain extent, that the reluctance to work with higher performance and difficulties in adapting to the new conditions of work are affected by the weakening of some cognitive skills in older people. As well as the fact that the lack of qualifications, lack of language skills and lack of computer skills do not allow employees to work with higher performance and cause problems with adapting to the new conditions of work. Also these 
named contexts require further analysis and investigation. Although the results of examination of these issues in developed countries suggest that the weakness of some of the physical skills of older workers are replaced by several other unique skills.

This means that there is an unequal treatment of older employees on the labor market and at work in Slovakia and the age of employees is one of the most discriminatory elements. This is therefore one of the main factors that cause problems with success on the labor market and at work of older people, despite the fact that the qualitative differentiating from the perspective of age is legislatively unacceptable, but there is a hidden form of discrimination. The solution to this problem is difficult and is strongly impeded by the fact that there is no specific legislative measures which would make it possible to employ older people without problems. This objective is not yet clearly defined, concrete and eligible for the whole society.

The measures that could prove helpful to solving this issue include organizational and legislative changes aiming at affirmative action and improving the approach to education and vocational training. Another efficient course of action could be support for flexible forms of employment for older workers and decreasing the levy burden.

The older generation is a specific part of society in general, which is mainly conditioned by the current cult of youth that affects social awareness at all levels - the attitudes of employers, which are often influenced by the general assumption that older workers are less adaptable, less productive, unwilling to accept change; government officials to resolve problems with success of older people on the labor market and at work through the prism of improvement of employment statistics. In some cases, there is discrimination, which is not only about the success on the labor market. Governmental and European programs for increasing employment are focused primarily on the youngest generation, on a group of people under 29 years.

The survey found that the employers, employees under 50 and employees aged 50 and older view the main problems that older workers face on the labour market differently, which suggests the existence of communication barriers, lack of a common dialogue and solidarity between generations. However, our findings regarding the behavior of subjects active on the labour market (i.e. government, employers and older employees) are not sufficient for definite proposal of efficient measures that would improve the position of older workers on the labour market. We are missing specific information regarding their behavior, especially when it comes to the group interests and how these interests relate to the solidarity principle. Further research in this area could prove to be useful for creation and implementation of efficient measures.

\section{References}

Aberdeen, L. and Bye, L-A. (2013), Challenges for Australian sociology: Critical ageing research - ageing well? Journal of Sociology, Vol. 49(1), pp. 3-21.

Androniceanu, A. and Ohanyan, G. (2016), Comparative Approach on Education and Healthcare in Romania and Bulgaria as Beneficiaries of the IMF Financial Assistance, Administratie si Management Public, (26), pp. 25-48.

Androniceanu, A. (2015), Good Democratic Governance Based on a New Model, Administratie si Management Public, (24), pp. 56-63.

Adler, G., Hilber, D. (2009), Industry Hiring Patterns of Older Workers, Research on Aging, Vol. 31, 1, pp. 69-88.

Barabaschi, B. (2015), Intergenerational Solidarity in the Workplace: Can It Solve Europe's Labor Market and Social Welfare Crises? SAGE Open, Vol. 5(4), 2158244015621464. 
Becerra-Alonso, D., Androniceanu, A., \& Georgescu, I. (2016), Sensitivity and Vulnerability of European Countries in Time of Crisis Based on a New Approach to Data Clustering and Curvilinear Analysis, Administratie si Management Public, (27), pp. 46-61.

Beck, V. (2014), Employers' views of learning and training for an ageing workforce, Management Learning, Vol. 45, No. 2, pp. 200-215.

Bednárik, R. a kol. (2014), Národná stratégia zamestnanosti, Štúdia komplexného programu zamestnanosti o spoločných strategických cieloch zamestnanosti a dlhodobých zámeroch na ich dosiahnutie, Vydáva: Inštitút pre výskum práce a rodiny, Bratislava, 2014. (cit. 27.02.2016), available at: https://www.employment.gov.sk/files/nsz_vedecka_studia_final.pdf.

Bleha, B., Vaňo, B. (2015), Niektoré teoretické a metodologické aspekty populačnej politiky a náčrt jej koncepcie pre Slovenskú republiku (cit. 05.03.2016), available at: http://www.infostat.sk/vdc/pdf/cl49.pdf.

Bohle, P., Pitts, C., Quinlan, M. (2010), Time to Call it Quits? The Safety and Health of Older Workers, International Journal of Health Services, Vol. 40, 1, pp. 23-41.

Burcin, B., Kučera, T. (2002), Stárnutí obyvatelstva a hranice důchodového věku, Demografie, Vol. 44, No. 1, pp. 30-34.

Carbonaro, G., Leanza, E., McCann, P. Medda, F. (2016), Demographic Decline, Population Aging, and Modern Financial Approaches to Urban Policy, International Regional Science Review, 10 Nov. 2016.

Canduela, J., Dutton, M., Johnson, S., Lindsay, C., McQuaid, R. W., Raeside, R. (2012), Ageing, skills and participation in work-related training in Britain: assessing the position of older workers, Work, employment and society, Vol. 26, 1, pp. 42-60.

Carra, C., Burlacu, S., \& Faggianelli, D. (2016), Violence Within Organizations In The Health And Medico-Social Sectors, Comparative Analysis France - Romania, Administratie si Management Public, (27), pp. 123-142.

Eurostat (2016), Employment and Social Inclusion Indicators, aviable at: http://ec.europa.eu/eurostat/web/employment-and-social-inclusionindicators/employment-guidelines

Fuinhas, J. A., Marques, A. C., Almeida, P., Nogueira, D., Branco T. (2016), Two Centuries of Economic Growth: International Evidence on Deepness and Steepness, Transformations in Business \& Economics, Vol. 15, No. 3 (39), pp. 192-206.

Gillion, C. (1991), Ageing Populations: Spreading the Costs, Journal of European Social Policy, Vol. 1, 2, pp. 107-128.

Green A. E. (2003), Labour Market Trends, Skill Needs and the Ageing of the Workforce: A Challenge for Employability? Local Economy, Vol. 18, 4, pp. 306-321.

Gregory, T. and Patuelli, R. (2015), Demographic ageing and the polarization of regions an exploratory space - time analysis, Environment and Planning A, Vol. 47, 5, pp. 1192 1210.

Higo, M., TA Khan, H. (2014), Global population aging: Unequal distribution of risks in ater life between developed and developing countries, Global Social Policy, Vol. 15, 2, pp. 146-166.

Hughes, M., Bigby, Ch., Tilbury, C. (2016), Australian social work research on ageing and aged care: A scoping review, Journal of SocialWork, 23 Jun 2016.

Cheung, Ch., Kwong, P., Raymond, K., Ngan, M. (2010), Age discrimination in the labour market from the perspectives of employers and older workers, International Social Work, Vol. 54, 1, pp. 118-136.

Cheung, F. and Wu, A. M. S. (2014), Social Identification, Perception of Aging, and Successful Aging in the Workplace, Journal of Career Development, Vol. 41(3), pp. 218-236. 
Cheung, F., Wu, A. M. S. and Yeung, D. Y. (2016), Factors Associated With Work Volition Among Aging Workers in Hong Kong, Journal of Career Development, Vol. 43(2), pp. 160-176.

Ilmarinen, J. (2009a), Aging and Work: An International Perspective, In: Sara J. Czaja and Joseph Sharit (eds.), Aging and Work. Issues and Implications in a Changing Landscape, TheJohns Hopkins University Press, pp. 51-73.

Ilmarinen, J. (2009b), Work Ability - a comprehensive concept for occupational health research and prevention. Edtorial, Scandinavian Journal of Work, Environment \& Health, Vol. 35(1), pp. 1-5.

Ilmarinen, J. (2012), Podpora aktívneho starnutia na pracovisku. Európska agentúra pre bezpečnost' a ochranu zdravia pri práci (Online) (Cit. 15.03.2016), available at: https://osha.europa.eu/sk/publications/articles/promoting-active-ageing-in-theworkplace.

Inštitút pre verejné otázky (IVO) (2012), Starši vek a l'udské práva. Silnejšia participácia, menej diskriminácie. Záverečná správa z výskumu, Bratislava (Cit. 15.03.2016), available at: http://www.ivo.sk/6765/sk/projekty/starsi-vek-a-ludske-prava-silnejsiaparticipacia-menej-diskriminacie.

Ji, H., Ling, J. and Lander, V. (2015), McCarthySuccessful Aging in the United States and China: A Theoretical Basis to Guide Nursing Research, Practice, and Policy, Journal of Transcultural Nursing, Vol. 26, No. 2, pp. 129-136.

Kate, A. (2013), Hamblin Active Ageing in the European Union: Policy Convergence and Divergence, Basingstoke: Palgrave Macmillan.

Kelly, G. A. and Lazarus, J. (2015), Perceptions of Successful Aging: Intergenerational Voices Value Well-Being, The International Journal of Aging and Human Development, Vol. 80, No. 3, pp. 233-247.

Kluge, F. A. (2012), The Fiscal Impact of Population Aging in Germany, Public Finance Review, Vol. 41, 1, pp. 37-63.

Kordos, M., Karbach, R. (2014), The Issue of Innovation in International Economics, Political Sciences, Law, Finance, Economics and Tourism, Vol III, Book Series: International Multidisciplinary Scientific Conferences on Social Sciences and Arts, pp. 653-661.

Koutsogeorgou, E., Davies, J. K., Aranda, K., Zissi, A., Chatzikou, M., Cerniauskaite, M., Quintas, R., Raggi, A. and Leonardi, M. (2014), Healthy and active ageing: Social capital in health promotion, Health Education Journal, Vol. 73, No. 6, pp. 627-641.

Latorre, J. M., Serrano, J. P., Ricarte, J., Bonete, B., Ros, L. and Sitges, E. (2015), Life Review Based on Remembering Specific Positive Events in Active Aging, Journal of Aging and Health, Vol. 27, No. 1, pp. 140-157.

Lisenkova, K., Mérette, M. (2014), Can an Ageing Scotland Afford Independence? National Institute Economic Review, Vol. 227, 1, pp. R32-R39.

Lisiankova, K. and Wright, R. E. (2009), Demographic Change and the European Union Labour Market, National Institute Economic Review, Vol. 194(1), pp. 74-81.

McPhedran, S. (2012), The Labor of a Lifetime?: Health and Occupation Type as Predictors of Workforce Exit Among Older Australians, Journal of Aging and Health, Vol. 24, 2, pp. 345-360.

Moulaert, T. and Biggs, S. (2013), International and European policy on work and retirement: Reinventing critical perspectives on active ageing and mature subjectivity, Human Relations, Vol. 66, No. 1, pp. 23-43.

Neuman, D. (2009), The Age Discrimination in Employment Act and the Challenge of Population Aging, Research on Aging, Vol. 31, 1, pp. 41-68. 
Nilsson, K., Östergren, P-O., Kadefors, R. and Albin, M. (2016), Has the participation of older employees in the workforce increased? Study of the total Swedish population regarding exit from working life, Scandinavian Journal of Public Health, March 17, 2016 as doi: $10.1177 / 1403494816637262$.

Nygård, C-H., Savinainen, M., Kirsi, T., Lumme-Sandt, K. (2011), Age Management during the Life Course, Tampere: Tampere University Press.

Páleník, V. (4014), Vplyv demografického vývoja na priemysel a úloha regionálnej, štátnej a európskej priemyselnej politiky pri zmierňovaní vplyvu nevyváženého vekového zloženia obyvatel'stva, Revidovaný návrh informačnej správy poradnej komisie pre priemyselné zmeny (CCMI) 31.03.2014 (cit. 24.02.2016), available at: https://webapi.eesc.europa.eu/.../EESC-2013-03321-00-02-PRI-TRA-SK...

Potančoková, M. Starnutie populácie Slovenska, Bratislava: VDC Infostat (2005) (cit.02.03.2016), available at: http://www.infostat.sk/vdc/pdf/StarnutieVDC.pdf.

Pracovný dokument Útvarov Komisie, Správa o krajine, Slovensko 2015, \{COM(2015) 85final $\}$ (cit. 26.02.2016), available at: http://ec.europa.eu/europe2020/pdf/csr2015/cr2015_slovakia_sk.pdf.

Radivojević, A., Pavlović, M., Milovanović, M., Stričević, L., 1, Dimić, M. (2016), Population Aging in Serbia. A Case Study of the Municipality of Bela Palanka, Journal of Family History, Vol. 41, 2, pp. 165-175.

Riach, K. (2007), 'Othering' older worker identity in recruitment, Human Relations, Vol. 60, 11, pp. 1701-1726.

Rychtařiková, J. (2002), Úspěšné stárnutí - leitmotiv 21. Století, Demografie, Vol. 44, No. 1, pp. 43-46.

Sanders, M. J. and McCready, J. W. (2010), Does Work Contribute to Successful Aging Outcomes in Older Workers? The International Journal of Aging and Human Development, Vol. 71(3), pp. 209-229.

Skare, M., Sinkovic, D. (2016), Isolating Long Cycles in Unemployment Rates of Croatia Using Spectral Modelling, Transformations in Business \& Economics, Vol. 15, No. 3C (39C), pp. 520-543.

Srovnalikova, P., Karbach, R. (2016), Tax Changes and Their Impact on Mnagerial Decision Making, Contemporary Issues in Theory and Practice of Management. 1st International Conference, Czestochowa: Univ Technol, pp. 410-418.

Svagzdiene, B., Kuklyte J. (2016), The Analysis of Factors which have Impact for Summary Innovation Index in Germany, Estonia and Lithuania, Transformations in Business \& Economics, Vol. 15, No. 2B (38B), pp. 784-799.

Taylor, Ph. (ed.) (2013), Older Workers in an Ageing Society: Critical Topics in Research and Policy, Cheltenham: Edward Elgar.

Tyrovolas, S. et al. (2015), The Role of Energy Balance in Successful Aging Among Elderly Individuals: The Multinational MEDIS Study, Journal of Aging and Health, Vol. 27(8), pp. 1375-1391.

Van Dalen, H. P., Henkens, K., Schippers, J. (2009), Dealing with older workers in Europe: a comparative survey of employers' attitudes and actions, Journal of European Social Policy, Vol. 19, 1, pp. 47-60.

Wale, A. (2011), The Ageing Population, InnovAiT, Vol. 4, 6, pp. 339-346.

Wallin, M., Hussi, T. (2011), Best practices in Age Management - evaluation of organisation cases, Final report of research project, available at: http://www.tsr.fi/database.

Weller, S. A. (2007), Discrimination, labour markets and the labour market prospects of older workers: what can a legal case teach us? Work, Employment \& Society, Vol. 21 (3), pp. 417-437. 